\title{
Investigations on the Fauna of Pyraloidea and Geometridae (Lepidoptera) of Nemrut Caldera Natural Monument
}

\author{
Kesran AKIN *1, Erdem SEVEN ${ }^{2}$ \\ ORCID: 0000-0003-2921-948X; 0000-0002-7587-5341
}

\author{
${ }^{1}$ Bitlis Eren University, Faculty of Arts and Sciences, Department of Biology, 13000, Bitlis, Turkey \\ ${ }^{2}$ Batman University, School of Tourism and Hotel Management, Department of Gastronomy and Culinary Arts, 72060 , \\ Batman, Turkey
}

\begin{abstract}
This study is conducted between May and October 2017 and 2018, during the day and night by field studies on the foothills of Nemrut Caldera and Mount Nemrut by targeting the detection of Pyraloidea and Geometridae moth species. As a result of the field studies, 93 taxa belonging to Pyraloidea and 52 species of Geometridae are determined. Of these taxa, 80 species belonging to the Pyraloidea and, 40 species belonging to the Geometridae have been identified for the first time in Nemrut Caldera. With these records, the number of Pyraloidea species in Nemrut Caldera increased to 94 and the number of Geometridae species increased to 58. And, of these taxa, 20 species of Pyraloidea, and 21 of Geometridae are new records for the Bitlis province. The number of pyraloid species in the Bitlis province has risen to 238 and also the number of geometrid species to 137.
\end{abstract}

Key words: Nemrut Caldera, Pyraloidea, Geometridae, Lepidoptera, Bitlis, Turkey

\section{Nemrut Kalderası Tabiat Anıtı Pyraloidea ve Geometridae (Lepidoptera) Faunası Üzerine Araştırmalar}

\section{Özet}

Bu çalışma 2017 ve 2018 yıllarının Mayıs-Ekim ayları arasında, Nemrut Kalderası ve Nemrut Dağı'nın eteklerinde yapılan arazi çalışmalarıyla, Pyraloidea ve Geometridae güve türlerinin tespiti hedeflenerek yürütülmüştür. Araştırmalar sonucunda, 93 Pyraloidea taksonu ve 52 Geometridae türü tespit edilmiştir. Bu taksonlardan 80 Pyraloidea ve 40 Geometridae türü Nemrut Kalderası'nda ilk kez tespit edilmiştir. Bu kayıtlarla birlikte Nemrut Kalderası'nda Pyraloidea tür sayıs1 94'e, Geometridae tür sayısı ise 58'e yükselmiştir. Yine bu taksonlardan 20 Pyraloidea ve 21 Geometridae türü Bitlis ili için yeni kayıt niteliğindedir. Bitlis ilindeki pyraloid tür sayısı 238'e, geometrid tür sayısı ise 137 'ye yükselmiştir.

Anahtar kelimeler: Nemrut Kalderası, Pyraloidea, Geometridae, Lepidoptera, Bitlis, Türkiye

\section{Introduction}

Pyraloidea are one of the largest superfamily of Lepidoptera, including nearly 16,000 identified species in two families, Pyralidae and Crambidae [1]. The wingspan in adults is between 6-95 mm. The head and haustellum scaly, labial palp are mostly linear and distinct, the maxillary palp is 4-segmented (uncommonly 2-3 segmented). The wing shape is usually quite elongated and the forewings are pointed. Adults are mostly nocturnal, some are crepuscular and a few are diurnal. There are various lifestyles in the biology of the larvae that are leaf folding, netting, body piercing, root and rash eater. They are harmful in almost all crops, forest trees and warehouse products [2]. Known Pyraloidea species in Bitlis is 218 and in Nemrut Caldera is 14 [3-4].

\footnotetext{
* Corresponding author / Haberleşmeden sorumlu yazar: Tel.: +905446049424; Fax.: +905446049424; E-mail: kesran@ gmail.com

(C) Copyright 2020 by Biological Diversity and Conservation $\quad$ Received: 13.05.2019; Published: 15.04.2020 
The geometrid moths form one of the richest family of Lepidoptera with about 21.000 defined species [5]. The geometrid moths are represented by 900 species in Europe [6] and by 684 species in Turkey [7]. Geometridae fauna in Turkey is examined in 208 genera of 6 subfamilies: Archiearinae, Orthostixinae, Geometrinae, Sterrhinae, Larentiinae and Ennominae. The subfamilies are distinguished according to vascular vein patterns. Geometrid adults are mostly nocturnal and are interested in various light sources. They show relationship with Drepanidae, Uraniidae and Pyralidae families when classified based on adult morphology. However, they can be distinguished by the larval morphology as well as, tympanal organ in the first abdominal segment in the adult and, the presence of the hard bristle bundles (chaetosema) between antenna and eye [8].

The study area, Nemrut Caldera Nature Monument, is located $15 \mathrm{~km}$ north of Tatvan district in the west of Van Lake basin and between the lands of Ahlat-Tatvan districts [9]. Caldera has an elliptical shape with 7 to $8 \mathrm{~m}$ diameter and $3050 \mathrm{~m}$ altitude [10]. The main lakes within the caldera are Nemrut Lake (or Big Lake), Ilica Lake and a fresh water lake, which is situated approximately $3 \mathrm{~km}$ east of the Big Lake. This lake is especially important for the local people engaged in animal husbandry [11]. Mount Nemrut contains 450 plant species, of which a total of 43 taxa are endemic to Turkey and, including about 21 rare nationwide [12-13]. Nemrut Caldera was designated as Natural Monument in 2003, Important Plant Area in 2005 and Important Nature Area in 2006 [9, 13-14]. Also, Koçak and Kemal [11] stated that the caldera can be described as the Insect Diversity Center.

In the Nemrut Caldera, the first comprehensive study on Lepidoptera was conducted by Kemal and Koçak [10]. In this study, the authors presented 87 butterfly species with 4 moth species and one of them is a geometrid moth, Aplocera columbata (Metzner, 1945). The last comprehensive study on Lepidoptera fauna in Nemrut Caldera was published by Koçak and Kemal [11]. In addition to the comparative analysis of habitat preferences of diurnal species, the study included 231 species of 21 families. 10 of these species are Pyraloidea and 16 are Geometridae species. (Pyraloidea: Catoptria mytilella (Hübner, [1805]); Ephelis cruentalis (Geyer, [1832]); Evergestis frumentalis (Linnaeus, 1761); E. umbrosalis (Fischer v. Röslerstamm, [1842]); Mecyna lutulentalis (Lederer, 1858); Metaxmeste sericatalis (Herrich-Schäffer, [1848]); Noctuelia superba (Freyer, [1844]); Nomophila noctuella ([Denis \& Schiffermüller], 1775); Pyrausta (s.str.) aurata (Scopoli, 1763); Tretopteryx pertusalis (Geyer, [1832]), Geometridae: Aplocera annexata (Freyer, [1830]); A. columbata (Metzner, 1845); A. plagiata (Linnaeus, 1758); Cidaria fulvata (Forster, 1771); Ematurga atomaria (Linnaeus, 1758); Entephria ignorata (Staudinger, 1892); Eupithecia mesogrammata Dietze, 1908; Gnophos (Dicrognophos) pseudosnelleni (Rjabov, 1964); Idaea rusticata ([Denis \& Schiffermüller], 1775); Neognopharmia stevenaria (Boisduval, 1840); Nychiodes (Eunychiodes) variabila Brandt, 1938; Orthostixis cribraria (Hübner, [1799]); Pydna bahara (Brandt, 1938); Scotopteryx bipunctaria ([Denis \& Schiffermüller], 1775); Selenia lunularia (Hübner, 1788); Thetidia persica Hausmann, 1996). Moreover, Kemal and Kocak [15] in their study on Pyraloidea presented new records for Turkey and for Nemrut Caldera; Megasis kocaki Akın, 2016, Pyrausta despicata (Scopoli, 1763), P. porphyralis ([Denis \& Schiffermüller], 1775) (also new for the fauna of Turkey), Sciota rhenella (Zincken, 1818). Recently, recording of Agonopterix dideganella (Amsel, 1972) (Depressaridae) species and its hostplant with larval parasitoid reported by Akın et al., [16] from Nemrut Caldera. Seven et al., [17] were described a new geometrid moth, Eupithecia nemrutica Seven, Mironov \& Akın, 2019 for the science from the study area.

\section{Materials and methods}

The studies were carried out in the inner parts of Nemrut Caldera and on the slopes of the mountain at 11 locations between May-October 2017 and 2018, during the day and night. Diurnal specimens were caught with sweep nets and UV light traps were used for capture of the nocturnal species. Researches were mostly carried out at night, because of the majority of the study materials were nocturnal. The collected samples are labeled after being softened and stretched. The samples were first distinguished according to their external morphologies. And, genital preparations were performed for unidentified species. The method applied by Robinson [18] was followed while preparing the genital structures. The all samples of Pyraloidea group and the duplets of Geometridae family are stored in the Zoology Research Laboratory of Bitlis Eren University. In addition to the collections of the authors, the main sources used in diagnostics are as follows: Pyraloidea: Amsel [19-21]; Bleszynski [22]; Leraut [23]; Roesler [24-25]; Slamka [26-29]; Goater et al., [30]. Geometridae: Hausmann, [6, 31]; Hausmann and Viidalepp, [32]; Leraut, [5]; Mironov, [33-34]; Skou and Sihvonen, [35].

The field studies are carried out 11 localities in Nemrut Caldera including:

1. Northeast slope, $2167 \mathrm{~m}, 38^{\circ} 63^{\prime} 96,9^{\prime \prime} \mathrm{N} 42^{\circ} 79^{\prime} 38^{\prime \prime} \mathrm{E}$, 2. Yayla remnant road, South pit, $2360 \mathrm{~m}, 38^{\circ} 61^{\prime} 01,6^{\prime \prime} \mathrm{N}$ $42^{\circ} 26^{\prime} 74,5^{\prime} \mathrm{E}, 3$. Yayla remnant road, South pit, $1 \mathrm{~km}$ to the big lake, $2303 \mathrm{~m}, 38^{\circ} 61^{\prime} 17,6^{\prime \prime N} 42^{\circ} 24 ' 48^{\prime \prime E}$, (Fig. 1$) 4$. Tatvan-Ahlat crossroad, $2322 \mathrm{~m}, 38^{\circ} 63^{\prime} 13,2^{\prime \prime} \mathrm{N} 42^{\circ} 25^{\prime} 29^{\prime \prime} \mathrm{E}$, (Fig. 2) 5. Between Çekmece Village-Hotel, Upper slope,

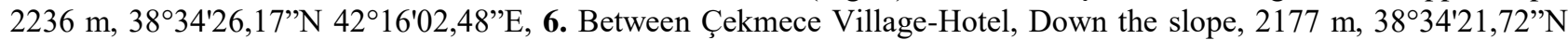
$42^{\circ} 16^{\prime} 10,62^{\prime}$ 'E, 7. Steam chimney, Curves, $2287 \mathrm{~m}, 38^{\circ} 63^{\prime} 95,2^{\prime} \mathrm{N} 42^{\circ} 24^{\prime} 81^{\prime \prime} \mathrm{E}, 8$. Large lake surroundings, $2257 \mathrm{~m}$, $38^{\circ} 38^{\prime} 38,99^{\prime \prime} \mathrm{N} 42^{\circ} 14^{\prime} 13,10^{\prime \prime} \mathrm{E}, 9$. Southeast side slope, near ropeway, $2463 \mathrm{~m}, 38^{\circ} 58^{\prime} 60,9^{\prime \prime} \mathrm{N} 42^{\circ} 26^{\prime} 82,4^{\prime \prime} \mathrm{E}, 10$. hub, $2408 \mathrm{~m}, 38^{\circ} 62^{\prime} 32,7^{\prime \prime} \mathrm{N} 42^{\circ} 26^{\prime} 00,9^{\prime}$ 'E, 11. Small lake, North flatness, $2296 \mathrm{~m}, 38^{\circ} 63^{\prime} 04,4^{\prime}{ }^{\circ} \mathrm{N} 42^{\circ} 27^{\prime} 06,6^{\prime \prime} \mathrm{E}$. 


\section{Results}

As a result of the field studies, 93 taxa (90 at species level, 3 at genus level) belonging to the Pyraloidea and 52 species of Geometridae were identified. The species are presented in alphabetical order within the families, subfamilies and genera. Species detected for the first time from Nemrut Caldera are marked with one asterisk (*) and new records for Bitlis province are marked with two asterisks (**) after the species name combinations.

Superfamily Pyraloidea Latreille, 1809

Family Crambidae Latreille, 1810

Subfamily Crambinae Latreille, 1810

Agriphila Hübner, [1825]

A. deliella (Hübner, [1813])** (Fig. 3)

A. poliella (Treitschke, 1832)**

A. tolli (Bleszynski, 1952)*

Ancylolomia Hübner, [1825]

A. palpella ([Denis \& Schiffermüller], 1775)**

Catoptria Hübner, [1825]

C. dimorphella (Staudinger, 1881)*

C. pinella (Linnaeus, 1758)*

Glaucocharis Meyrick, 1938

G. euchromiella (Ragonot, 1895)*

Metacrambus Bleszynski, 1957

M. carectellus (Zeller, 1847)*

Pediasia Hübner, [1825]

P. matricella (Treitschke, 1832)*

Subfamily Glaphyriinae (= Evergestinae, Noordinae) W. T. M. Forbes, 1923

Evergestis Hübner, [1825]

E. infirmalis (Staudinger, 1870)*

E. mundalis (Guenée, 1854)*

E. segetalis (Herrich-Schäffer, $([1855]) * *$

E. umbrosalis (Fischer v. Röslerstamm, [1842])

Subfamily Odontiinae Guenée, 1854

Cynaeda Hübner, [1825]

C. gigantea (Staudinger, 1879)*

C. superba (Freyer, [1845])

Ephelis Lederer, 1863

E. cruentalis (Geyer, [1832])

Metaxmeste Hübner, [1825]

M. sericatalis (Herrich-Schäffer, [1848])

Phlyctaenomorpha Amsel, 1970

P. sinuosalis (Le Cerf, [1910])*

Tegostoma Zeller, 1847

T. perlepidalis (Guenée, 1854)*

Subfamily Pyraustinae Meyrick, 1890

Achyra Guenée, 1849

A. nudalis (Hübner, 1796)**

Loxostege Hübner, [1825]

L. turbidalis (Treitschke, 1829)**
Paracorsia Marion, 1959

P. repandalis ([Denis \& Schiffermüller], 1775)*

Pyrausta Schrank, 1802

$P$. aerealis (Hübner, 1793)*

P. armeniaca Slamka, 2013**

$P$. castalis Treitschke, $1829 *$

P. despicata (Scopoli, 1763)

P. limbopunctalis (Herrich-Schäffer, [1849])**

$P$. porphyralis ([Denis \& Schiffermüller], 1775)

P. sanguinalis (Linnaeus, 1767)*

Sitochroa Hübner, [1825]

S. palealis ([Denis \& Schiffermüller], 1775)**

Subfamily Scopariinae Guenée, 1854

Anarpia Chapman, 1912

A. incertalis (Duponchel, 1832)*

Eudonia Billberg, 1820

E. mercurella (Linnaeus, 1758)*

Subfamily Spilomelinae Guenée, 1854

Mecyna Doubleday, [1849]

M. subsequalis (Herrich-Schäffer, 1855)

Metasia Guenée, 1854

M. comealis Amsel, 1961**

Nomophila Hübner, [1825]

$N$. noctuella ([Denis \& Schiffermüller], 1775)

Udea Guenée, [1845]

U. confinalis (Lederer, 1858)*

U. dispunctalis (Guenée, 1854)*

U. ferrugalis (Hübner, 1796)*

Udea sp.

Family Pyralidae Latreille, 1809

Subfamily Phycitinae Zeller, 1839

Acritonia Amsel, 1954

A. comeella Amsel, 1954*

Acrobasis Zeller, 1839

A. consociella (Hübner, [1813])*

A. dulcella (Zeller, 1848)*

Ancylosis Zeller, 1839

A. cinnamomella (Duponchel, 1836)*

A. dumetella (Ragonot, 1887)*

Ancylosis sp.

Anerastia Hübner, [1825]

A. lotella (Hübner, [1813])** 
Arsissa Ragonot, 1893

A. ramosella (Herrich-Schäffer, [1855])*

Asalebria Amsel, 1953

A. exasperata (Staudinger, 1879)*

Bradyrrhoa Zeller, 1848

B. gilveolella (Treitschke, 1833)*

B. imperialella (Ragonot, 1887)*

B. mesobaphella Ragonot, 1888**

Cadra Walker, 1864

C. furcatella (Herrich-Schäffer, [1849])*

Ematheudes Zeller, 1867

E. punctellus (Treitschke, 1833)*

Ephestia Guenée, 1845

E. unicolorella Staudinger, 188*

E. welseriella (Zeller, 1848)*

Epiepischnia Amsel, 1954

E. pseudolydella Amsel, 1954*

Epischnia Hübner, [1825]

E. cretaciella Mann, $1869^{* *}$ (Fig 4)

Episcythrastis Meyrick, 1937

E. tabidella (Mann, 1864)*

Etiella Zeller, 1839

E. zinckenella (Treitschke, 1832)*

Euzophera Zeller, 1867

E. luculentella Ragonot, $1888^{* * *}$

Homoeosoma Curtis, 1833

H. inustellum Ragonot, 1884*

H. nimbellum (Duponchel, [1837])**

H. sinuellum (Fabricius, 1794)*

Hypochalcia Hübner, [1825]

H. ahenella ([Denis \& Schiffermüller], 1775)*

Hypsotropa Zeller, 1848

H. limbella Zeller, 1848*

Isauria Ragonot, 1887

I. dilucidella (Duponchel, 1836)*

Keradere Whalley, 1970

K. lepidella (Ragonot, 1887)*

Keradere argyrophanes (Meyrick, 1937)**

Lambaesia Rebel, 1903

L. fumosella (Ragonot, 1887)**

Laristania Amsel, 1951

L. taftanella (Amsel, 1954)*

Laristania sp.

Megasis Guenée, 1845

M. kocaki Akın, 2016

Metallosticha Rebel, 1901

M. argyrogrammos (Zeller, 1847)*
Monotonia Amsel, 1955

M. straminella (Zerny, 1914)*

Myrlaea Ragonot, 1887

M. albistrigata (Staudinger, 1881)*

Pempelia Hübner, [1825]

P. alpigenella (Duponchel, 1836)**

Pempeliella Caradja, 1916

P. sororiella (Zeller, 1839)*

Phycitodes Hampson, 1917

P. albatella (Ragonot, 1887)*

$P$. binaevella (Hübner, [1813])*

P. lacteella (Rothschild, 1915)*

P. saxicola (Vaugham, 1870)*

Pima Hulst, 1888

P. christophori (Ragonot, 1887)*

Polyochodes Chrétien, 1911

Polyochodes farsella (Amsel, 1951)*

Psorosa Zeller, 1846

P. dahliella (Treitschke, 1832)*

P. maraschella Caradja, 1910*

Pterothrixidia Amsel, 1954

P. squalidella (Eversmann, 1842)**

Sciota Hulst, 1888

S. rhenella (Zincken, 1818)

Selagia Hübner, [1925]

S. spadicella (Hübner, 1796)*

Synoria Ragonot, 1888

S. antiquella (Herrich-Schäffer, [1855])*

Uncinus Amsel, 1951

U. nobilellus (Ragonot, 1887)*

Subfamily Pyralinae Latreille, 1809

Aglossa Latreille, [1796]

A. pinguinalis (Linnaeus, 1758)**

Pyralis Linnaeus, 1758

P. perversalis (Herrich-Schäffer, [1849])*

Synaphe Hübner, [1825]

S. bombycalis ([Denis \& Schiffermüller], 1775)*

Family Geometridae Leach, 1815

Subfamily Geometrinae Leach, 1815

Thalera Hübner, [1823]

T. fimbrialis (Scopoli, 1763)

Subfamily Larentiinae Duponchel, 1845

Aplocera Stephens, 1827

A. annexata (Freyer, [1830])

A. columbata (Metzner, 1845)

A. opificata (Lederer, 1870)*

A. plagiata (Linnaeus,1758) 
Catarhoe Herbulot, 1951

C. permixtaria (Guenée, [1858])*

Cidaria Treitschke, 1825

C. fulvata (Forster, 1771)

Docirava Walker, [1863]

D. mundata (Staudinger, 1892)* (Fig. 5)

Euphyia Hübner, [1825]

E. frustata (Treitschke, 1828)**

Eupithecia Curtis, 1825

E. amasina Bohatsch, $1893 * *$

E. distinctaria Herrich-Schäffer, [1848]**

E. fuscicostata Christoph, $1887 * *$

E. gueneata Millière, $1862 * *$

E. impurata (Hübner, [1813])**

E. intricata Zetterstedt, [1839]**

E. nemrutica Seven, Mironov \& Akın, 2019

E. oblongata (Thunberg, 1784)**

E. pusillata (Fabricius, 1787)**

E. schiefereri Dietze, 1904**

E. succenturiata (Linnaeus, 1758)**

Perizoma Hübner, [1825]

P. bifaciata (Haworth, 1809)**

Scotopteryx Hübner, [1825]

S. bipunctaria ([Denis \& Schiffermüller], 1775)

Subfamily Ennominae Duponchel, 1845

Aspitates Treitschke, 1825

A. quadripunctata (Goeze, 1781)*

Charissa Curtis, 1826

C. libanotica (Wehrli, 1931)**

C. luticiliata (Christoph, 1887)**

C. obscurata ([Denis \& Schiffermüller], 1775)**

C. wanensis (Wehrli, 1936)*

Crocallis Treitschke, 1825

C. inexpectata Warnecke, $1940 * *$

Gnophos Treitschke, 1825

G. sartatus (Treitschke, 1827)**
Neognopharmia Wehrli, 1953

N. stevenaria (Boisduval, 1840)

Nychiodes Lederer, 1853

N. variabila Brandt, 1938

Ourapteryx Leach, 1814

O. sambucaria (Linnaeus, 1758)*

Stegania Guenée, [1845]

S. dilectaria (Hübner, 1790)*

Synopsia Hübner, [1825]

S. sociaria (Hübner, [1799])**

Synopsidia Djakonov, 1935

S. phasidaria (Rogenhofer, 1873)*

Subfamily Orthostixinae Meyrick, 1892

Orthostixis Hübner, [1823]

O. cribraria (Hübner, [1799])

Subfamily Sterrhinae Meyrick, 1892

Idaea Treitschke, 1825

I. consanguinaria (Lederer, 1853)**

I. ossiculata (Lederer, 1871)*

I. proclivata (Fuchs, 1902)**

I. rusticata ([Denis \& Schiffermüller], 1775)

I. trigeminata (Haworth, [1809])*

Lythria Hübner, [1823]

L. cruentaria (Hufnagel, 1767)*

Rhodostrophia Hübner, [1823]

R. vibicaria (Linnaeus, 1761)*(Fig. 6)

R. badiaria (Freyer, [1841])**

R. cuprinaria (Christoph, 1876)*

Scopula Schrank, 1802

S. beckeraria (Lederer, 1853)*

S. decorata ([Denis \& Schiffermüller], 1775)

S. immistaria (Herrich-Schäffer, [1852])*

S. incanata (Linnaeus, 1758)**

S. marginepunctata (Goeze, 1781)*

S. ornata (Scopoli, 1763)*

S. submutata (Treitschke, 1828)*

\section{Conclusions and discussion}

In this study, 90 species belonging to Pyraloidea were identified from Nemrut Caldera and out of these species, 3 taxa were diagnosed at the genus level. The identified species according to family and subfamily belonging to these families are; Crambidae (38): Crambinae (9), Glaphyriinae (4), Odontiinae (6), Pyraustinae (11) Scopariinae (2), Spilomelinae (6); Pyralidae (52): Phycitinae (49), Pyralinae (3) (Table 1).

Table 1. Distribution of the species belonging to Pyraloidea

\begin{tabular}{lll}
\hline Family & Subfamily & Species number \\
\hline \multirow{4}{*}{ Crambidae } & Crambinae & 9 \\
& Glaphyriinae & 4 \\
& Odontiinae & 6 \\
& Pyraustinae & 11 \\
& Scopariinae & 2 \\
Pyralidae & Spilomelinae & 6 \\
& Phycitinae & 49 \\
& Pyralinae & 3 \\
\hline & Total & 90 \\
\hline
\end{tabular}


As can be seen from Table 1, the highest number of the determined species from the study area is Phycitinae subfamily and the least species is Scopariinae subfamily.

Pyraloidea has known with 14 species from Nemrut Caldera and 218 species from Bitlis province [3-4]. In this study, 80 of the identified species are new reports for Nemrut Caldera and, 20 of them are new records for Bitlis province (Table 2). The highest number of registrations for both regions is determined in Phyicitinae subfamily. And, in Odontinae and Scopariinae subfamilies were not found any new record for Bitlis. Moreover, the number of the species belonging to the Pyraloidea increased to 94 in Nemrut Caldera and 238 in Bitlis.

Table 2. New records of Pyraloidea species for Nemrut Caldera and Bitlis

\begin{tabular}{llll}
\hline Family & Subfamily & Nemrut Caldera & Bitlis \\
\hline \multirow{4}{*}{ Crambidae } & Crambinae & 9 & 3 \\
& Glaphyriinae & 3 & 1 \\
& Odontiinae & 3 & - \\
& Pyraustinae & 9 & 5 \\
& Scopariinae & 2 & - \\
\hline Pyralidae & Spilomelinae & 4 & 1 \\
& Phycitinae & 47 & 9 \\
& Pyralinae & 3 & 1 \\
\hline & Total & 80 & 20 \\
\hline
\end{tabular}

In Geometridae family, a total of 52 species are found in the study area in Geometrinae, Larentiinae, Ennominae, Orthostixinae and Sterrhinae subfamilies. And, 21 of the identified species are found for the first time in Bitlis Lepidoptera fauna. The maximum number of the species is determined from the subfamily of Larentiinae. Also, the least number includes the subfamilies Geometrinae and Orthostixinae. Similarly, Larentiinae subfamily has the most new records with 12 new species for the Lepidoptera fauna of Bitlis Province (Table 3). According to the results of the research, the number of geometrid moths in the field raised to 58 [11]. Also, the number of geometrid moths in Bitlis has reached to 137 species an increase of about $18 \%$ with addition 21 species to previously known 116 species [3].

Table 3. Number of the species according to Geometridae subfamilies and new records for Bitlis

\begin{tabular}{lll}
\hline Subfamily & Species number & New records for Bitlis \\
\hline Geometrinae & 1 & - \\
Larentiinae & 21 & 12 \\
Ennominae & 13 & 5 \\
Orthostixinae & 1 & - \\
Sterrhinae & 16 & 4 \\
\hline Total & $\mathbf{5 2}$ & $\mathbf{2 1}$ \\
\hline
\end{tabular}

The results of the study show that Nemrut Caldera is very rich in Pyraloidea and Geometridae species. In this respect, it is thought that it should be studied the other groups belonging to Lepidoptera.

\section{Acknowledgements}

The authors would like to thank Bitlis Eren University Scientific Research Projects Coordination Unit for supporting this study with the BEBAP 2017.08 project number..

\section{References}

[1] Munroe, E., Solis, M. A. (1999). Pyraloidea. In N. Kristensen (Eds.), Lepidoptera, Moths and Butterflies, Vol. 1, Arthropoda, Insect. Vol.4, Part 35. Handbook of Zoology (pp. 233-256). Berlin, Walter de Gruyter \& Co.

[2] Heppner, J. B. (2008). Snout Moths (Lepidoptera: Pyralidae). In J. L. Capinera (Eds.), Encyclopedia of Entomology (pp. 3430-3431). Springer.

[3] Kemal, M., Kızıldağ, S., Koçak, A. Ö. (2020). Updated faunistic list of the Lepidoptera of Bitlis Province (East Turkey) based on the info-systems of the Cesa with some information on the projects. Priamus, 18(4), 156-252.

[4] Koçak, A. Ö., \& Kemal, M. (2019). First updated geographical codes used in the publications of the Cesa. Priamus, 17(4), 319-360.

[5] Leraut, P. (2009). Moths of Europe. Volume 2 Geometrid Moths. N.A.P. ed., Verrières-le-Buisson.

[6] Hausmann, A. (2001). The Geometrid Moths of Europe Vol. 1. Apollo Books.

[7] Koçak, A. Ö., \& Kemal, M. (2018). A synonymous and distributional list of the species of the Lepidoptera of Turkey. Cent. ent. Stud., Memoirs, 8, 1-487. 
[8] Kemal, M., \& Seven, E. (2013). Siirt ilinde Şirvan'ın Geometridae türlerinin ekolojisi ve faunası üzerine araştırmalar (Leidoptera). Priamus (Suppl.), 29, 1-41.

[9] Eken, G., Bozdoğan, M., İsfendiyaroğlu, S., Kılıç, D. T., Lise, Y. (2006). Türkiye’nin Önemli Doğa Alanları. Doğa Derneği, Ankara, 2: 348-351.

[10] Kemal, M., \& Koçak, A. Ö. (2006). Diurnal Lepidoptera in the Nemrut Crater (East Turkey). Cent. ent. Stud., Misc. Pap., 101, 1-8.

[11] Koçak, A. Ö., \& Kemal, M. (2015). Nemrut Kalderası'nın diurnal Lepidopterlerinin habitat tercihlerinin karşılaştırmalı analizi (Bitlis, Türkiye). Priamus Suppl., 37, 1-57.

[12] Tatlı, A. (1982). Nemrut Dağının Bitki Sosyolojisi ve Bitki Ekolojisi Yönünden İncelenmesi. Atatürk Üniv. Fen Fak. Der., 1(1), 537-549.

[13] Özhatay, N., Byfield, A., Atay, S. (2005). Türkiye’nin 122 Önemli Bitki Alanı. WWF Türkiye, İstanbul.

[14] Doğa Koruma ve Milli parklar Genel Müdürlüğ̈̈. (2013-2014). Tabiat Anıtları. http://www.milliparklar.gov.tr/korunanalanlar/ta.htm (Date of access: 19.02.2017).

[15] Kemal, M., \& Koçak, A. Ö. (2017). New and little known Pyraloidea of Turkey, with some faunistical notes (Lepidoptera). Cesa News, 130, 1-43.

[16] Akın, K., Gençer, L., \& Seven, E. (2018). The larval food-plant of Agonopterix dideganella (Amsel, 1972) (Lepidoptera: Depressaridae) and its new larval parasitoid Copidosoma sosares (Walker) record. Biological Diversity and Conservation, 11(3), 38-40.

[17] Seven, E., Mironov, V., Akın, K. (2019). A new species of Eupithecia Curtis (Lepidoptera: Geometridae, Larentiinae) from Turkey. Zootaxa, 4668(3), 443-447. https://doi: 10.11646/zootaxa.4668.3.9

[18] Robinson, G. S. (1976). The Preparation of slides of Lepidoptera genitalia with special reference to the Microlepidoptera. Entomologist's Gazette, 27, 127-132.

[19] Amsel, H. G. (1951). Die Microlepidopteren der Brandt'schen Iran Ausbeute III. Ark. Zool., 1(36), $525-563$.

[20] Amsel, H. G. (1954). Die Microlepidopteren der Brandt'schen Iran Ausbeute IV. Ark. Zool., 6(16), $255-326$.

[21] Amsel, H. G. (1961). Die Microlepidopteren der Brandt'schen Iran Ausbeute V. Ark. Zool., 13(17), $323-445$.

[22] Bleszynski, S. (1965). Crambinae. In Amsel, H. G., Reisser, H., Gregor, F. (Eds.), Microlepidoptera Palaearctica 1 (pp. 1-553). Verlag Georg Fromme \& Co, Wien.

[23] Leraut, P. (2014). Moths of Europe. Volume 4 Pyralids 2. N.A.P. ed., Verrières-le-Buisson.

[24] Roesler, R-U. (1973). Trifine Acrobasiina (1. Teilband der Phycitinae). In Amsel, H. G., Reisser, H., Gregor, F. (Eds.), Microlepidoptera Palaearctica 4 (pp. 752+137). Verlag Georg Fromme \& Co, Wien.

[25] Roesler, R-U. (1993). Quadrifine Acrobasiina Erster Teil (2. Teilband der Phycitinae). In Amsel, H. G., Reisser, H., Gregor, F. (Eds.), Microlepidoptera Palaearctica 8 (pls 1-82+xxii+305). Verlag G. Braun, Karlsruhe.

[26] Slamka, F. (2008). Pyraloidea of Europe (Lepidoptera) Volume 2. Crambinae \& Schoenobiinae. Identification, Distribution, Habitat, Biologie. Bratislava.

[27] Slamka, F. (2011). Pyraloidea of Europe (Lepidoptera) Volume 1. Pyralinae, Galleriinae, Epipaschiinae, Cathariinae \& Odontiinae. Identification, Distribution, Habitat, Biologie. Bratislava.

[28] Slamka, F. (2013). Pyraloidea of Europe (Lepidoptera) Volume 3. Pyraustinae \& Spilomelinae. Identification, Distribution, Habitat, Biologie. Bratislava.

[29] Slamka, F. (2019). Pyraloidea of Europe (Lepidoptera) Volume 4. Phycitinae- Part 1. Bratislava.

[30] Goater B, Nuss M, Speidel W, (2005). Pyraloidea I (Crambidae: Acentropinae, Evergestinae, Heliothelinae, Schoenobiinae, Scopariinae). In P. Humer \& O. Karsholt (Eds.), Microlepidoptera of Europe 4. 1-304. Apollo Books.

[31] Hausmann, A. (2004). The Geometrid Moths of Europe Vol. 2 Sterrhinae. Apollo Books.

[32] Hausmann, A., Viidalepp, J. (2012). The Geometrid Moths of Europe. 3. Apollo Books, Stenstrup.

[33] Mironov, V. (2003). The Geometrid Moths of Europe Vol. 4 Larentiinae II. Apollo Books.

[34] Mironov, V. (2013). New species and checklist of Turkish Eupithecia Curtis (Geometridae, Larentiinae). Zootaxa, 3717 (1), 39-52. https://doi: 10.11646/zootaxa.3717.1.3

[35] Skou, P., Sihvonen, P. (2015). Subfamily Ennominae I. In Hausmann, A. (Eds.), The geometrid moths of Europe 5 (pp. 1-657). Brill \& Leiden. 


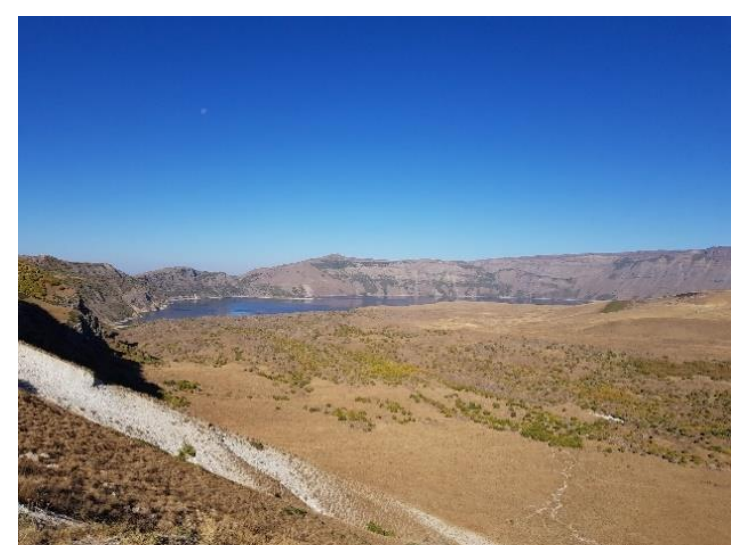

1.

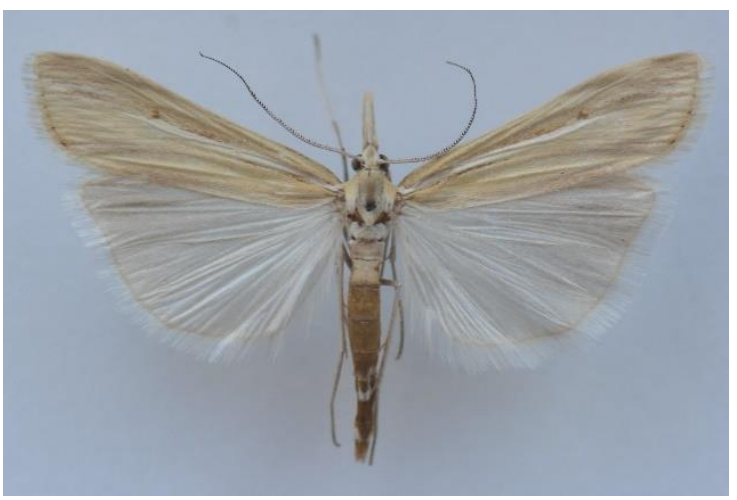

3.

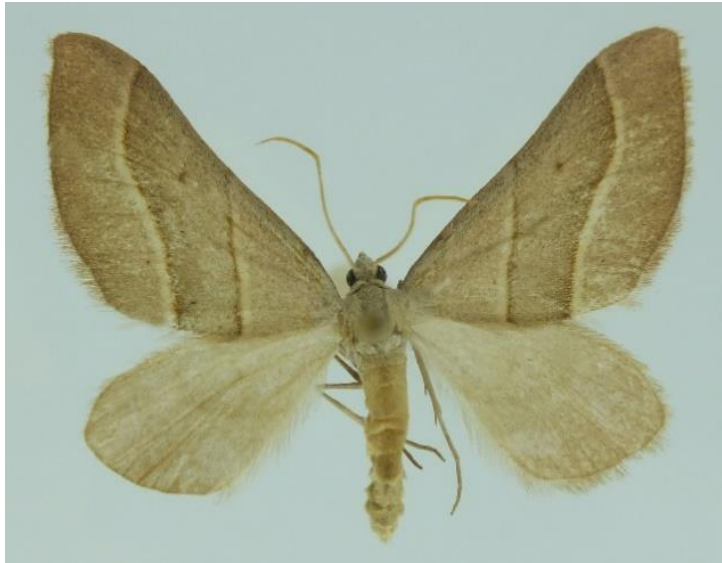

5.

Figures: 1. Yayla remnant road, South pit, $1 \mathrm{~km}$ to the big lake, 2. Tatvan-Ahlat crossroad, 3. Agriphila deliella (Hübner, [1813]) (Crambidae), 4. Epischnia cretaciella Mann, 1869 (Pyralidae), 5. Docirava mundata (Staudinger, 1892) (Geometridae), 6. Rhodostrophia vibicaria (Linnaeus, 1761) (Geometridae)

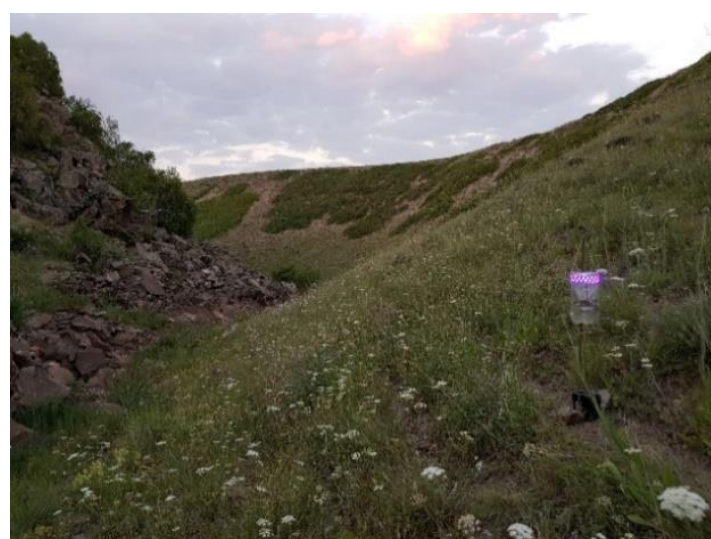

2.

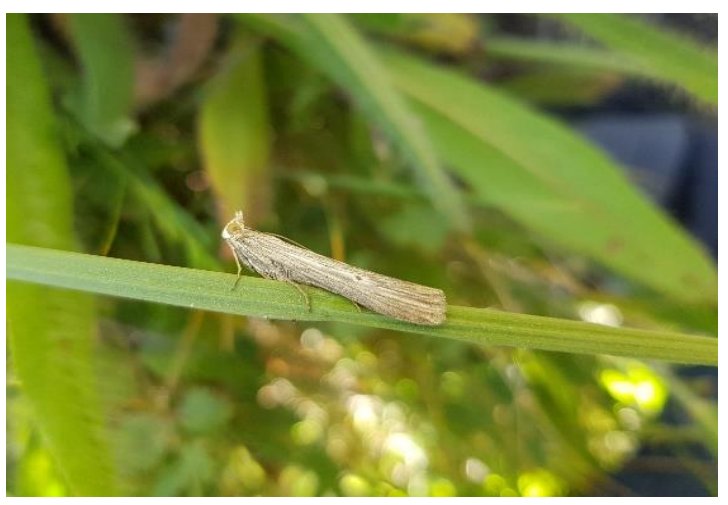

4.

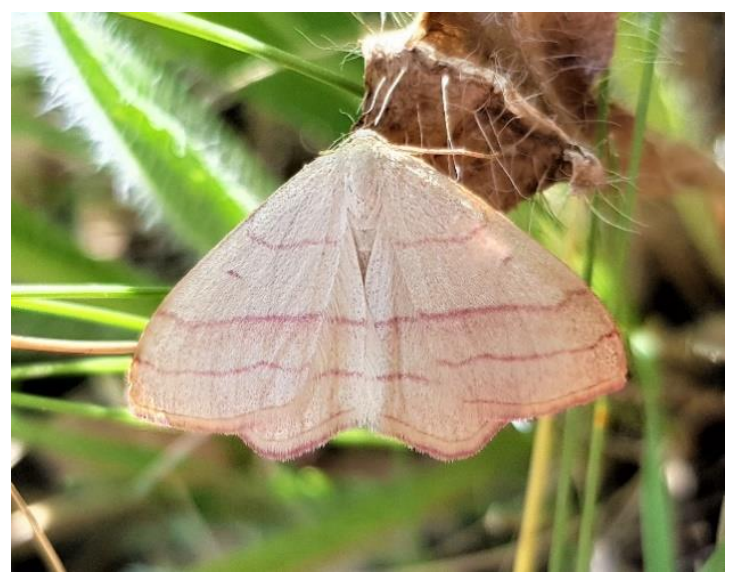

6. 